\title{
Diagnostic accuracy of cytology and biopsy in primary bronchial carcinoma
}

\author{
C R PAYNE, P G I STOVIN, V BARKER, S McVITTIE, AND J E STARK \\ From Papworth Hospital, Papworth Everard, Cambridge, UK
}

\begin{abstract}
The accuracy of diagnosis of cell type obtained from sputum cytology, bronchial aspirate, bronchial biopsy, or percutaneous lung biopsy in 161 cases of confirmed primary lung cancer has been examined and the pretreatment histological diagnosis has been compared with the final diagnosis made after surgical resection or necropsy. The yield of positive diagnoses of malignancy obtained by each method of investigation in each cell type showed that cytological examination of sputum was the most accurate method, but a high degree of accuracy was also obtained by bronchoscopic aspiration and bronchial biopsy. Percutaneous lung biopsy was the most effective, but the least accurate, means of obtaining carcinoma cells. The level of diagnostic accuracy was highest in patients with squamous cell carcinoma. Accurate pretreatment diagnosis of patients with adenocarcinoma was particularly difficult, and only $20 \%$ of these cases were correctly diagnosed by investigation. Of seven patients with adenocarcinoma and a positive diagnosis of malignancy made on percutaneous lung biopsy, none was correctly diagnosed. The causes of error in diagnosis of cell type of primary lung cancer are discussed.
\end{abstract}

Recent developments in cancer chemotherapy and the advent of chemotherapy specific for the different histological types of lung cancer have increased the importance of accurate pretreatment histological diagnosis. We can find no published studies comparing the accuracy of commonly used diagnostic procedures in predicting the histological type of lung tumours. We have therefore examined the accuracy of diagnosis of histological type of cytology and biopsy techniques in 161 cases of confirmed primary lung cancer. In this report we have been concerned primarily with the accuracy of diagnosis of cell type and less concerned with the yield as defined by the number of positive diagnoses obtained.

\section{Methods}

We reviewed laboratory and case records of all cases diagnosed as lung cancer in the years 1974 7 inclusive, and from whom tissue was obtained at surgery or necropsy. Tissue for final diagnosis was obtained by thoracotomy in 138 cases and by post-mortem examination in 23. All specimens examined cytologically or histologically before thoracotomy (and all those examined before a final presumptive diagnosis was accepted in those cases not subjected to operation) are included in the survey.

All patients had one or more investigations, and many were investigated by a combination of techniques.

Only the results of cytology of sputum specimens regarded as satisfactory by the pathologist on the basis of the presence of alveolar macrophages were included in the study.

All but two of the bronchoscopies were carried out using the rigid bronchoscope under general anaesthesia. The results achieved by fibreoptic bronchoscopy, used in two patients, were excluded from the study.

BRONCHIAL BIOPSY

Bronchial biopsies were performed using Negus biopsy forceps through a rigid bronchoscope. Material was formalin fixed and embedded in paraffin. Sections were routinely stained with haematoxylin, phloxine, and saffron. Additional stains for mucin were performed where this was considered helpful.

NEEDLE BIOPSY

Percutaneous lung biopsy with either a shortbevelled 19 gauge aspiration needle or a Rotex 
biopsy needle was used to investigate peripheral lung opacities. Smears were prepared and stained with Papanicolaou's stain.

\section{CYTOLOGICAL TECHNIQUES}

The Pasteur pipette was the best instrument for selecting sputum or centrifuged deposit from bronchial aspirates for smearing. Smears were fixed with Cytofix and stained with Papanicolaou's stain. After needle aspiration smears were made directly and immediately fixed in a Coplin jar of methanol.

\section{TERMINOLOGY}

True histological type was taken to be that of the surgically resected or post-mortem specimen.

Presumptive histological type was that obtained from cytological examination of sputum, bronchoscopic or percutaneous lung aspirate, or from histological examination of tissue obtained by bronchial biopsy.

The presumptive diagnosis was considered "correct" if it agreed with the true cell type. Where malignancy was diagnosed but the presumptive diagnosis differed from the true diagnosis the result was recorded as "incorrect positive." The absence of malignant cells was recorded as a negative result.

\section{NOMENCLATURE OF HISTOLOGICAL TYPES}

The classification of lung cancer cell types is not yet completely standardised, and the WHO system, introduced in 1967, has not gained universal acceptance (Yesner et al, 1965; Matthews, 1973; Reinilä and Dammert, 1974). It is necessary therefore to define the classification used in this paper.

Besides the typical squamous cell carcinomas with keratin formation or prickle cells, we have included carcinomas growing as sheets showing some stratification between the basal layer and a flatter surface cell. These latter poorly differ- entiated squamous cell carcinomas would be put into WHO group IV.2 or possibly into group II.2. Only a few of the exfoliated cells from this poorly differentiated squamous cell group show the features of non-keratinised squamous cells.

Adenocarcinomas have to show glandular, acinar, or alveolar arrangement of cells, or epithelial types of glycoprotein must be shown. Although there were no examples, WHO II.4 would be included in this definition. Likewise no carcinoid adenomas were present in this series. Giant cell carcinomas were included in adenocarcinomas.

A few carcinomas showed a combination of squamous and adenocarcinoma-that is group $\mathrm{V}$ of WHO classification. Only those carcinomas of WHO II. 1 and 3 were classed as oat cell carcinoma. Carcinomas that on the material available did not fit into one of the above groups were classed as undifferentiated carcinomas.

\section{Results}

Of those patients having operations the true histological diagnosis in $94(68 \%)$ was squamous cell carcinoma, in $37(27 \%)$ adenocarcinoma, in four $(3 \%)$ oat cell carcinoma, in two $(1 \%)$ undifferentiated carcinoma, and in one $(1 \%)$ adenosquamous carcinoma. Of those diagnosed at necropsy, the true histological diagnosis in five $(22 \%)$ was squamous cell carcinoma, in eight $(35 \%)$ adenocarcinoma, in eight $(35 \%)$ oat cell carcinoma, in one $(4 \%)$ undifferentiated carcinoma, and in one $(4 \%)$ adenosquamous carcinoma.

DIAGNOSTIC YIELD OF EACH TYPE OF INVESTIGATION (table 1)

This study was designed to assess the diagnostic accuracy of various techniques used in the diag-

Table 1 Yield obtained with each method of investigation. (Percentages in parentheses)

\begin{tabular}{|c|c|c|c|c|c|c|}
\hline & \multicolumn{6}{|c|}{ True histological type } \\
\hline & Squamous & Oat & Adeno & Undifferentiated & Adenosquamous & Total \\
\hline $\begin{array}{l}\text { Sputum cytology } \\
\text { No tested } \\
\text { No showing malignancy }\end{array}$ & $\begin{array}{l}46 \\
32(70)\end{array}$ & $\begin{array}{l}9 \\
5(56)\end{array}$ & $\stackrel{21}{5(24)}$ & $\begin{array}{l}1 \\
0(0)\end{array}$ & $\begin{array}{l}0 \\
0(0)\end{array}$ & $\begin{array}{l}77 \\
42 \text { (55) }\end{array}$ \\
\hline $\begin{array}{l}\text { Bronchial aspirate } \\
\text { No tested } \\
\text { No showing malignancy }\end{array}$ & $\begin{array}{l}72 \\
42(58)\end{array}$ & $\begin{array}{l}9 \\
3(33)\end{array}$ & $\begin{array}{l}24 \\
4 \text { (17) }\end{array}$ & $\begin{array}{l}2 \\
0(0)\end{array}$ & $\begin{array}{l}2 \\
1(50)\end{array}$ & $\begin{array}{l}109 \\
50(46)\end{array}$ \\
\hline $\begin{array}{l}\text { Bronchial biopsy } \\
\text { No tested } \\
\text { No showing malignancy }\end{array}$ & $\begin{array}{l}67 \\
48(72)\end{array}$ & $\begin{array}{l}3 \\
2(67)\end{array}$ & $\begin{array}{l}14 \\
9(64)\end{array}$ & $\begin{array}{l}3 \\
1(33)\end{array}$ & 1 (100) & $\begin{array}{l}88 \\
61(69)\end{array}$ \\
\hline $\begin{array}{l}\text { Percutaneous biopsy } \\
\text { No tested } \\
\text { No showing malignancy }\end{array}$ & $\begin{array}{l}16 \\
14(88)\end{array}$ & $\begin{array}{l}0 \\
0(0)\end{array}$ & $\begin{array}{l}8 \\
7(88)\end{array}$ & $1(100)$ & 1 & $\begin{array}{l}26 \\
23(88)\end{array}$ \\
\hline
\end{tabular}


nosis of lung cancer. Comparisons of different techniques, however, must be based on both diagnostic yield and diagnostic accuracy, and therefore we present the yield of each investigation in table 1.

Percutaneous lung biopsy was the most successful procedure since malignant cells were detected in $23(88 \%)$ of 26 cases. Carcinoma was diagnosed in $69 \%$ of 88 cases investigated by bronchial biopsy, and in about half of those cases investigated by cytological examination of sputum or bronchial aspirate

\section{DIAGNOSTIC ACCURACY OF EACH TYPE OF INVESTIGATION}

Sputum cytology (table 2)

Malignant cells were seen on cytological examination of sputum in 42 cases, and in $37(88 \%)$ the presumptive and true diagnoses agreed. Of 31 presumptive diagnoses of squamous cell carcinoma, one case had an oat cell tumour and one an adenocarcinoma; and of five cases with a presumptive diagnosis of oat cell carcinoma, one had a squamous cell tumour. A presumptive diagnosis of adenocarcinoma on sputum cytology was correct on all four occasions, but both cases with a cytological diagnosis of undifferentiated carcinoma had squamous cell tumours.
Bronchial aspirate (table 3)

Of 50 cases in which carcinoma was diagnosed on examination of bronchial aspirate, the cell type was correctly predicted in $42(84 \%)$. Of 45 patients with a presumptive diagnosis of squamous cell carcinoma, the cell type was correctly predicted in $40(91 \%)$, but three had adenocarcinoma, one an oat cell carcinoma, and one an adenosquamous carcinoma. Of three patients with a presumptive diagnosis of adenocarcinoma, the cell type was correct in only one. The other two had a squamous cell and an oat cell tumour. The presumptive diagnosis was correct in the one patient with oat cell carcinoma.

Bronchial biopsy (table 4)

Carcinoma was diagnosed on bronchial biopsy in 61 cases, of which the cell type was correctly predicted in $49(80 \%)$. Of 47 patients with a presumptive diagnosis of squamous cell carcinoma, 43 $(92 \%)$ were correctly diagnosed, but three had adenocarcinoma and one adenosquamous carcinoma. Five of eight cases with a presumptive diagnosis of adenocarcinoma were correctly diagnosed, but the others had a squamous cell tumour, an oat cell tumour, and an undifferentiated tumour. All five presumptive diagnoses of undifferentiated carcinoma were erroneous, four being

Table 2 Accuracy of sputum cytology (42 cases with a diagnosis of malignancy on cytological examination of sputum)

\begin{tabular}{|c|c|c|c|c|c|c|}
\hline \multirow{2}{*}{$\begin{array}{l}\text { Presumptive histological } \\
\text { type }\end{array}$} & \multirow[t]{2}{*}{ No of patients } & \multicolumn{5}{|c|}{ True histological type } \\
\hline & & Squamous & Oat & Adeno & Undifferentiated & Adenosquamous \\
\hline Squamous & 31 & 29 & 1 & 1 & 0 & 0 \\
\hline Oat & 5 & 1 & 4 & $\mathbf{0}$ & 0 & 0 \\
\hline Adeno & 4 & 0 & 0 & 4 & 0 & 0 \\
\hline Undifferentiated & 2 & 2 & $\mathbf{0}$ & 0 & 0 & 0 \\
\hline Adenosquamous & 0 & 0 & 0 & 0 & 0 & 0 \\
\hline
\end{tabular}

Table 3 Accuracy of bronchial aspirate cytology (50 cases with a diagnosis of malignancy on cytological examination of bronchial aspirate)

\begin{tabular}{|c|c|c|c|c|c|c|}
\hline \multirow{2}{*}{$\begin{array}{l}\text { Presumptive histological } \\
\text { type }\end{array}$} & \multirow[t]{2}{*}{ No of patients } & \multicolumn{5}{|c|}{ True histological type } \\
\hline & & Squamous & Oat & Adeno & Undifferentiated & Adenosquamous \\
\hline Squamous & 45 & 40 & 1 & 3 & 0 & 1 \\
\hline Oat & 1 & 0 & 1 & 0 & 0 & 0 \\
\hline Adeno & 3 & 1 & 1 & 1 & 0 & 0 \\
\hline Undifferentiated & 1 & 1 & 0 & 0 & $\mathbf{0}$ & 0 \\
\hline Adenosquamous & $\mathbf{0}$ & $\mathbf{0}$ & 0 & $\mathbf{0}$ & 0 & $\mathbf{0}$ \\
\hline
\end{tabular}


Table 4 Accuracy of bronchial biopsy histology (61 cases with a diagnosis of malignancy on examination of bronchial biopsy)

\begin{tabular}{|c|c|c|c|c|c|c|}
\hline \multirow{2}{*}{$\begin{array}{l}\text { Presumptive histological } \\
\text { type }\end{array}$} & \multirow[t]{2}{*}{ No of patients } & \multicolumn{5}{|c|}{ True histological type } \\
\hline & & Squamous & Oat & Adeno & Undifferentiated & Adenosquamous \\
\hline Squamous & 47 & 43 & 0 & 3 & 0 & 1 \\
\hline Oat & 1 & $\mathbf{0}$ & 1 & 0 & 0 & 0 \\
\hline Adeno & 8 & 1 & 1 & 5 & 1 & 0 \\
\hline Undifferentiated & 5 & 4 & 0 & 1 & $\mathbf{0}$ & 0 \\
\hline Adenosquamous & 0 & 0 & 0 & 0 & 0 & $\mathbf{0}$ \\
\hline
\end{tabular}

squamous cell tumours and one an adenocarcinoma. The one case of oat cell carcinoma was correctly diagnosed.

\section{Percutaneous lung biopsy (table 5)}

Carcinoma was presumptively diagnosed in 23 cases by percutaneous lung biopsy and was correct in $11(48 \%)$, all of whom had squamous cell tumours. Of eight patients with an erroneous presumptive diagnosis of squamous cell carcinoma, six had adenocarcinoma, one undifferentiated carcinoma, and one adenosquamous carcinoma in the resected or necropsy specimen. The one patient presumptively diagnosed as having oat cell carcinoma had squamous cell cancer, and of three patients with presumptive diagnoses of undifferentiated carcinoma, two had squamous cell tumours and one an adenocarcinoma.
DIAGNOSTIC ACCURACY IN EACH HISTOLOGICAL TYPE (table 6)

Squamous cell carcinoma

The level of diagnostic accuracy was highest in patients with squamous cell carcinoma-about $90 \%$ for investigation by sputum cytology, bronchial aspiration, or bronchial biopsy and $78 \%$ by percutaneous lung biopsy. Nine cases were incorrectly diagnosed as undifferentiated carcinoma, two as oat cell carcinoma, and two as adenocarcinoma.

\section{Oat cell carcinoma}

Sputum cytology was the most accurate diagnostic procedure, and in $80 \%$ of cases the presumptive diagnosis agreed with the true diagnosis.

Two of three cases were incorrectly diagnosed by cytological examination of bronchial aspirate

Table 5 Accuracy of percutaneous lung biopsy cytology (23 cases with a diagnosis of malignancy made by percutaneous lung biopsy)

\begin{tabular}{|c|c|c|c|c|c|c|}
\hline \multirow{2}{*}{$\begin{array}{l}\text { Presumptive histological } \\
\text { type }\end{array}$} & \multirow[t]{2}{*}{ No of patients } & \multicolumn{5}{|c|}{ True histological type } \\
\hline & & Squamous & Oat & Adeno & Undifferentiated & Adenosquamous \\
\hline Squamous & 19 & 11 & 0 & 6 & 1 & 1 \\
\hline Oat & 1 & 1 & $\mathbf{0}$ & 0 & 0 & 0 \\
\hline Adeno & 0 & 0 & 0 & $\mathbf{0}$ & 0 & 0 \\
\hline Undifferentiated & 3 & 2 & 0 & 1 & $\mathbf{0}$ & 0 \\
\hline Adenosquamous & 0 & 0 & 0 & 0 & 0 & $\mathbf{0}$ \\
\hline
\end{tabular}

Table 6 Diagnostic accuracy of each method of investigation for each cell type

\begin{tabular}{|c|c|c|c|c|c|c|c|c|c|c|c|c|}
\hline \multirow{2}{*}{$\begin{array}{l}\text { True histological } \\
\text { type }\end{array}$} & \multicolumn{3}{|c|}{ Sputum cytology } & \multicolumn{3}{|c|}{ Bronchial aspirate } & \multicolumn{3}{|c|}{ Bronchial biopsy } & \multicolumn{3}{|c|}{ Percutaneous lung biopsy } \\
\hline & $\begin{array}{l}\text { No } \\
\text { Positive }\end{array}$ & $\begin{array}{l}\text { No } \\
\text { Correct }\end{array}$ & $\begin{array}{l}\% \\
\text { Correct }\end{array}$ & $\begin{array}{l}\text { No } \\
\text { Positive }\end{array}$ & $\begin{array}{l}\text { No } \\
\text { Correct }\end{array}$ & $\begin{array}{l}\% \\
\text { Correct }\end{array}$ & $\begin{array}{l}\text { No } \\
\text { Positive }\end{array}$ & $\begin{array}{l}\text { No } \\
\text { Correct }\end{array}$ & $\stackrel{\%}{\text { Correct }}$ & $\begin{array}{l}\text { No } \\
\text { Positive }\end{array}$ & $\begin{array}{l}\text { No } \\
\text { Correct }\end{array}$ & $\stackrel{\%}{\text { Correct }}$ \\
\hline Squamous & 32 & 29 & 90 & 42 & 40 & 95 & 48 & 43 & 87 & 14 & 11 & 78 \\
\hline Oat & 5 & 4 & 80 & 3 & 1 & 33 & 2 & 1 & 50 & 0 & 0 & 0 \\
\hline Adeno & 5 & 4 & 80 & 4 & 1 & 25 & 9 & 5 & 55 & 7 & $\mathbf{0}$ & $\mathbf{0}$ \\
\hline Undifferentiated & $\mathbf{0}$ & $\mathbf{0}$ & 0 & $\mathbf{0}$ & 0 & 0 & 1 & 0 & 0 & 1 & 0 & 0 \\
\hline Adenosquamous & $\mathbf{0}$ & $\mathbf{0}$ & 0 & 1 & 0 & 0 & 1 & 0 & $\mathbf{0}$ & 1 & $\mathbf{0}$ & $\mathbf{0}$ \\
\hline
\end{tabular}


-one as squamous cell carcinoma and one as adenocarcinoma. The last case was also incorrectly diagnosed on bronchial biopsy as adenocarcinoma. No case with oat cell carcinoma had a percutaneous lung biopsy.

\section{Adenocarcinoma}

Of 45 cases with adenocarcinoma, only nine $(20 \%)$ were correctly diagnosed by investigation. The presumptive diagnosis was squamous cell carcinoma in 11 cases.

Sputum cytology was the most accurate technique. In four cases $(80 \%)$ the presumptive diagnosis was correct, while one case was incorrectly diagnosed as having a squamous cell carcinoma. Bronchial aspirate and bronchial biopsy techniques yielded incorrect cell types in $75 \%$ and $44 \%$ respectively. In both groups there were four incorrect diagnoses-three as squamous cell carcinoma and one as undifferentiated carcinoma. Accuracy of diagnosis by percutaneous lung biopsy was poor. Of eight cases, seven were incorrectly diagnosed. In six of these the presumptive diagnosis was squamous cell carcinoma and in one undifferentiated carcinoma.

\section{Undifferentiated carcinoma}

Of three cases with undifferentiated carcinoma, positive diagnoses were made in two and both were incorrect. The presumptive diagnosis in one was adenocarcinoma (bronchial biopsy) and in one squamous cell carcinoma (percutaneous lung biopsy). There were no correct diagnoses in this group.

\section{Adenosquamous carcinoma}

One patient with adenosquamous carcinoma had an incorrect presumptive diagnosis of squamous cell carcinoma made by bronchial aspiration, bronchial biopsy, and percutaneous biopsy. There were no correct diagnoses in the two patients with this type of carcinoma.

\section{Discussion}

Until recently investigation of suspected bronchial carcinoma was primarily concerned with obtaining evidence of malignancy. Correct prediction of the true cell type was less important and did not alter the management of the individual patient. With the recognition that surgery is usually contraindicated in cases of oat cell cancer because of the frequency of metastatic spread, and with the increasing availability of specific chemotherapy for different histological types of lung cancer, the correct prediction of true cell type has assumed greater importance.

The frequency of individual cell types in our patients reflects their selection on the basis of surgical resection (in $86 \%$ of our cases) or postmortem examination ( $14 \%)$. It is not necessarily representative of all patients with primary lung cancer. For this reason we have a higher proportion of squamous cell carcinoma $(61.5 \%)$ and adenocarcinoma $(27.9 \%)$ than other studies (Shinton 1963; Yesner et al, 1965; Oswald et al, 1971) and relatively fewer patients with oat cell carcinoma $(7.5 \%)$ and undifferentiated carcinoma $(1.9 \%)$.

Our success rate in accurately predicting the true cell type by sputum cytology $(88 \%)$ is comparable to the $84 \%$ of Oswald et al (1971) in a similar investigation. More specifically, where the presumptive diagnosis was squamous cell carcinoma on cytological examination of sputum, we have found that the likelihood of the diagnosis being correct was $94 \%$. The accuracy of diagnosis by cytological examination of bronchial aspirate was similar to that achieved by sputum cytology. The overall yield of positive diagnoses made on cytological examination of sputum $(55 \%)$ is comparable to that achieved in other studies $(58 \%$ Farber and Mandel, 1960; 62\%-Duguid and Huish, 1963; 59\%-Oswald et al, 1971).

Bronchial biopsy provided a high yield of positive diagnoses of malignancy $(69 \%)$ and a high degree of accuracy in predicting cell type $(80 \%)$. The yield is greater where there is visible tumour, but we also found "blind" bronchial biopsy to be a useful procedure where there is no visible endo- ? bronchial abnormality. Positive diagnoses of 윽 malignancy were made in $45 \%$ of such cases and over half of these $(60 \%)$ were correct, as compared with $82 \%$ yield and $88 \%$ diagnostic accuracy in biopsy specimens from bronchoscopically visible tumour.

In our hands percutaneous lung biopsy was the most effective means of obtaining carcinoma cells $N$ $(88 \%)$ but the least accurate $(48 \%)$. Malignant cells were found in $86 \%$ of aspiration needle biopsies by Kline and Neal (1978) and in $77 \%$ of $\omega$ similar biopsies by Francis (1977). Needle biopsy produces a different cytological picture from that usually encountered in exfoliative cytology, be it $\mathbb{D}$ sputum or bronchial aspirate. The cells from the centre of the carcinoma tend to be aspirated in 70 such a way that they smear as flat sheets of cells $\underset{\mathbb{D}}{\stackrel{0}{0}}$ irrespective of the cell type. In exfoliated cell preparations such flat sheets would suggest squamous $\stackrel{\unrhd}{\unrhd}$ cell differentiation whereas rounded (three dimensional) clumps are characteristic of adenocar- 
cinoma. Three dimensional cell clumps are unusual in needle biopsies, and one has to look for the presence of terminal plates or microacini as more reliable guides to the diagnosis of adenocarcinoma. The nuclear morphology may also be an important aid. Often there is insufficient material for providing a satisfactory smear for staining for mucin. Other authors have experienced this difficulty (Bedrossian and Rybka, 1976; Francis, 1977). These features were not appreciated at first so that we have initially under-diagnosed adenocarcinoma and over-diagnosed squamous cell carcinoma. Despite this cause for diagnostic imprecision, needle biopsy is a highly successful technique for obtaining cancer cells from peripheral pulmonary tumours.

The diagnosis of adenocarcinoma poses several diagnostic difficulties apart from specific problems associated with needle biopsy. Not all malignant cells with large cytoplasmic vacuoles are adenocarcinomas. Degenerate squamous cells may also show this feature. A study of the nucleus may help because a large nucleolus in a vesicular nucleus is characteristic of adenocarcinoma, whereas an irregular hyperchromatic nucleus is characteristic of squamous cell carcinoma. Where the nucleus and cytoplasm are indeterminate there is a tendency, if squamous metaplasia is also present, to call these indeterminate malignant cells squamous carcinoma, even though it is known that one may see squamous metaplasia of the bronchial superficial epithelium when it is stretched or distorted by a deeper mucosal carcinoma of any cell type. These difficulties are reflected in our results, adenocarcinoma being the least reliably diagnosed type. Two-thirds of the presumptive diagnoses in this group were incorrect, the commonest incorrect diagnosis being squamous carcinoma.

Squamous cell carcinoma was the type with the most frequent correct presumptive diagnosis. Highly differentiated tumours were easily recognised. Where the presumptive diagnosis was incorrect, the squamous cell tumour was usually poorly differentiated and in these cases the commonest incorrect diagnosis was undifferentiated carcinoma.
We think that future studies of the methods used to diagnose lung cancer should include an assessment of the accuracy of diagnosis of cell type as well as the yield of diagnosis of malignancy.

\section{References}

Bedrossian, C W M, and Rybka, D L (1976). Bronchial brushing during fiberoptic bronchoscopy for the cytodiagnosis of lung cancer: comparison with sputum and bronchial washings. Acta Cytologica, 20, 446-453.

Duguid, H L D, and Huish, D W (1963). Clinical evaluation of cytodiagnosis in bronchial carcinoma. British Medical Journal, 2, 287-291.

Farber, S M, and Mandel, W (1960). Diagnosis of bronchogenic carcinoma-cytologic. In Tumours of the Chest, edited by D M Spain, p 67. Grune and Stratton, New York.

Francis, D (1977). Transthoracic fine-needle aspiration biopsy. Acta Pathologica Microbiologica Scandinavica, section A, 85, 230-234.

Kline, T S, and Neal, H S (1978). Needle aspiration biopsy: a critical appraisal. Journal of the American Medical Association, 239, 36-39.

Matthews, M (1973). Morphologic classification of bronchogenic carcinoma. Cancer Chemotherapy Reports, part 3, 4, suppl 2, 299-301.

Oswald, N C, Hinson, K F W, Canti, G, and Miller, A B (1971). The diagnosis of primary lung cancer with special reference to sputum cytology. Thorax, 26, 623-631.

Reinilä, A, and Dammert, K (1974). An attempt to use the WHO typing in the histological classification of lung carcinomas. Acta Pathologica Microbiologica Scandinavica, section A, 82, 783-789.

Shinton, N K (1963). The histological classification of lower respiratory tract tumours. British Journal of cancer, XVII, No 2, 213-221.

Yesner, R, Gerstl, B, and Auerbach, O (1965). Application of the World Health Organisation classification of lung carcinoma to biopsy material. Annals of Thoracic Surgery, 1, 33-49.

Requests for reprints to: Dr J E Stark, Papworth Hospital, Papworth Everard, Cambridge CB3 8RE. 